205

Received: August 29, 2015

Accepted: November 15, 2015
Macedonian Journal of Animal Science, Vol. 5, No. 2, p-p. 101-105 (2015)

In print: ISSN $1857-6907$

On line: ISSN $1857-7709$

UDC: 637.5 ' 62.053

Original scientific paper

\title{
RHEOMETRIC INVESTIGATIONS OF BEEF MUSCLE TISSUE IN DIFFERENT PERIODS OF AUTOLYSIS
}

\author{
Oksana Savinok \\ Odessa National Academy of Food Technologies, Odessa, Ukraine \\ savoksamit@mail.ru
}

\begin{abstract}
Rational parametres on the basis of experimental data of measurement rheological characteristics of a muscular fabric of beef are received and proved by a penetration method. The control point was L.dorsi between 7-8 back vertebras. The researches are spent by means of dynamic penetrometer at the use ofconic indentors with angles at tops $30^{\circ}, 20^{\circ}, 10^{\circ}$ and effort of resistance of a product equal $0.5 \mathrm{~kg}$. It is established that the greatest value of the depth of immersing is received at a cone of $10^{\circ}$. The chosen cone provides the minimum disorder of experimental data that allows to consider it rational and to use for researchesof rheological characteristics of the whole musclemeat of raw materials.
\end{abstract}

Key words: dynamic penetrometer; rheological characteristics; autolysis; muscle beef

\section{РЕОМЕТРИСКИ ИСТРАЖУВАЊА НА МУСКУЛНО ТКИВО ОД ГОВЕДСКО МЕСО ВО РАЗЛИЧНИ ПЕРИОДИ ОД АВТОЛИЗАТА}

\begin{abstract}
Врз основа на експерименталните податоци од мерењето на реолошките карактеристики на мускулното ткиво од говедското месо се утврдени параметри добиени и докажани со методот на пенетрација. Контролната точка беше L. dorsi меѓу 7-8 пршлен. Истражувањето е направено со динамичен пенетрометар со употреба на конусни индентори со агли на врвовите од $30^{\circ}, 20^{\circ}, 10^{\circ}$ и отпор на производот од $0,5 \mathrm{~kg}$. Утврдено е дека најголема длабочина е добиена со конус од $10^{\circ}$. Избраниот конус обезбедува минимална нејаснотија кај експерименталните податоци, што дозволува тие да се разгледаат рационално и да се употребат за истражувања на реолошки карактеристики на целото мускулно месо од суровината.
\end{abstract}

Клучни зборови: динамичен пенетрометар; реолошки карактеристики; автолиза; говедски мускул

\section{INTRODUCTION}

Initial properties of raw materials by manufacture products of meat which in many respects depend on the conditions of cultivation, primary processing and refrigerating storage have essential value. In a complex these factors predetermine kinetics of biochemical transformations on which level technological properties of meat depend. The properties which predetermine tenderness and juiciness of a ready product concern rheological characteristics of an integra piece ofmeat. The rheological characteristics of meat can be studied by various methods. A. Poldvere and others used. gravitational impulse method и texture measurement method (Warner-Bratzler method) for meat texture evaluation during ageing. Instrumental measurement of shear force and texture parameters in accordance with standard PN-ISO 11036 were carried out on pork by W. Migdat and others. The texture was analyzed using a TA-XT2 Texture Analyzer (Stable Micro Systems) with an attachment in the form of a cylinder $50 \mathrm{~mm}$ in diameter. [2]. The most studied and informative indicator for meat as an elastical and flexible bodyislimit pressure of shift defined by a penetrative method [3, 4].

On the base of a penetration method the measurement of depth of immersing indentor $(\mathrm{h}$, $\mathrm{mm}$ ) is at the expense of gravity or the compulsory introduction, expressed in the penetrative size (hp), under the given conditions of measurement (a type of indentor; weight or effort of introduction) which 
depends directly on a product consistence. The measurement of numerical values of size of a penetration is possible at the expense of the gravity at the use of static penetrometer, or at the expense of compulsory introduction of indentor at use dynamic penetrometer [3]. Unit of measure of penetration is the conditional linear size equal of 0.1 $\mathrm{mm}$. Penetrometers allow to define a complex of rheological characteristics, both in relative, and in absolute sizes, proceeding from initial measured size of a penetration. At use of static penetrometer penetrative size given indentor (it is defined for certain given time of immersion, usually $5 \mathrm{sec}$ onds, when conditional-instant deformations of investigated objectend), or the maximum size of a penetration, which appropriates to the achievement of an equilibriative condition between gravity and resistance of a product. At the use of dynamic penetrometer, the force of resistance of a product at which achievement the penetration size is fixed, and dynamic limiting pressure of shift (DPNS) [3] is calculated.

Static penetrometers, especially abroad (the USA, Germany, Japan, etc.), have found in research and industrial laboratories, dynamic ones because of the compactness, small weight and technical safety - are preferably usedat the manufacture.

The researches spent by scientists of MGUPP [5] prove thet the use as a working part of penetrometer of a conic indentor with an angle wuth top $60^{\circ}$ for viscos and plastic biosystems. For elastical and flexible bodies to which of an integral piece of meatof whole piece concerns, the use of such working body is irrational, because of low accuracy of measurement, at the expense of insignificant introduction of indentor in a product. At the task of great value of force of product resistance, the introduction of conic indentor will increase that will cause a considerable destruction of meattissue. Therefore, the definition of rational parametres of measurement of rheological characteristics of a muscular fabric of meat with a penetrative method was a problem of the given work. For the execution of this task was necessary to dorheometrical researches.

\section{MATERIAL AND METHODS}

Considering that the obtained data will be recommended for the use in industrial conditions, the research objects was a group of hulks of cattle, carcasses grown up in one farm under identical conditions of fattening. The control point was L.dorsi between 7-8 back vertebras.

For complex definition rheological propertive, with a penetrative method, was necessary to establish the rational fixed effort of resistance of a product at which the depth of indentor introduction would be from 0.5 to 0.9 from the maximum value. The rational effort of resistance of a product is set on the penetrometer, with its help the achievement of depth of introduction of the indentor in the measured environment is registered. The measuring working part has been chosen the most widespread conic indentors, which geometrical form allows to prove a conclusion of their constant theoretically. Necessary dependences for definition of constants of conic indentors, were received by researchers - Rebinder P. A., Volarovich M. P., Agranat N. N. and Shirokov M. F., Aret V.A., Kosoy V. D., Karpychev V. A., Abramov A. N., etc. - with various objects.

For the solution of problem, it was necessary to spend complex rheometric researches including this choice: a rational corner of conic indentor at top within the limits of $10^{\circ}$ to $30^{\circ}$ the rational set effort of introduction at the chosen angle of a cone.

Carrying out of experiment is carried out with small-sized portable penetrometer which mark was PPM-4, its image is in the Fig. 1. By means of the given devicethe fixed sizes of a penetration for chosen indentors numbness for achievement of the given effort of resistance of a muscular fabric of meat were fixed. Originally in our experiments the effort of resistance of a product equal $0.5 \mathrm{~kg}$ was shoseng which showed further the perspectivity of the use of the given size.

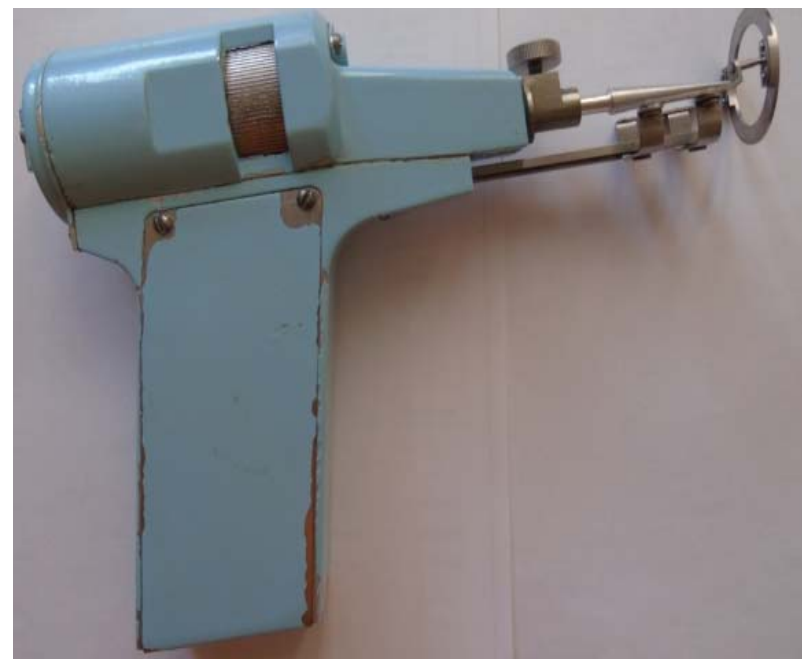

Fig. 1. Small-sized portable penetrometer PPM-4 m 


\section{RESULTS AND DISCUSSION}

With the object of a choice of a rational corner of a conic indentor for measurement of rheological characteristics the whole muscle raw materials the reseachrs were spent on hulks in a vapour condition (in 1 hour after slaughter) and in a condition postdeath shifteness numbness (in 44 hours) when it is possible to observe an essential difference in strength properties. Besides the strength properties depend on the structure of meat raw materials, that is from the arrangement of fibres. Therefore experimental researches are spent as along, and across fibres. With the introduction of a conic indentor in a muscular tissue of meat along fibres, which directed to cross-section and across fibres - in a longitudinal section. In the last case, the strength of meat is much more in comparison with meat in which measurements were spent along fibres. In the given series of experiments the measurements were spent with sixfold frequency.

Analyzing the results (Table 1) for samples with a longitudinal arrangement of the muscles, received at the use of conic indentor with angles at top $30^{\circ}, 20^{\circ}, 10^{\circ}$, we see that the depth of introduction (h, mm) was changed accordingly from 18.7 to 20.2; from 21.7 to 22.7 and from 24.7 to 25.6 ; thus average arithmetic values are equal accordingly $19.4,22.18,25.18$. In process of reduction of the size of a cone corner at top the depth of introduction of indentor in the sample increases at the expense of that the error of measurement from 4.12 $\%$ to $2.32 \%$ decreases.

Table 1

Change of depth of introduction of a cone in meat with is longitudinal and cross-section located muscles in 1 hour after slaughter

\begin{tabular}{|c|c|c|c|c|c|c|c|c|c|c|c|c|}
\hline \multirow{3}{*}{$\begin{array}{c}\text { Number } \\
\text { of } \\
\text { measurements }\end{array}$} & \multicolumn{6}{|c|}{$\begin{array}{l}\text { Longitudinal muscle } \\
\text { Angle of a cone }\end{array}$} & \multicolumn{6}{|c|}{$\begin{array}{l}\text { Transverse muscle } \\
\text { Angle of a cone }\end{array}$} \\
\hline & \multicolumn{2}{|r|}{$30 \mathrm{P}$} & \multicolumn{2}{|r|}{$20 \mathrm{P}$} & \multicolumn{2}{|r|}{$10 \mathrm{P}$} & \multicolumn{2}{|r|}{$30 \mathrm{P}$} & \multicolumn{2}{|r|}{$20 \mathrm{P}$} & \multicolumn{2}{|r|}{$10 \mathrm{P}$} \\
\hline & $\begin{array}{c}\mathrm{h} \\
\mathrm{mm}\end{array}$ & $\begin{array}{c}\text { Meas. error } \\
\%\end{array}$ & $\begin{array}{c}\mathrm{h} \\
\mathrm{mm}\end{array}$ & $\begin{array}{l}\text { Meas. error } \\
\%\end{array}$ & $\begin{array}{c}\mathrm{h} \\
\mathrm{mm}\end{array}$ & $\begin{array}{l}\text { Meas. error } \\
\%\end{array}$ & $\begin{array}{c}\mathrm{h} \\
\mathrm{mm}\end{array}$ & $\begin{array}{c}\text { Meas. error } \\
\%\end{array}$ & $\mathrm{~h}$ & $\begin{array}{c}\text { Meas. error } \\
\%\end{array}$ & $\begin{array}{c}\mathrm{h} \\
\mathrm{mm}\end{array}$ & $\begin{array}{l}\text { Meas. error } \\
\%\end{array}$ \\
\hline 1 & 16.1 & -0.42 & 18.5 & 1.77 & 21.2 & -0.24 & 22.5 & -3.45 & 25.4 & -0.13 & 27.6 & -1.66 \\
\hline 2 & 15.9 & 0.83 & 19.1 & -1.42 & 21.3 & -0.71 & 21.6 & 0.69 & 25.9 & -2.10 & 27.2 & -0.18 \\
\hline 3 & 16.3 & -1.66 & 18.6 & 1.24 & 21.4 & 1.65 & 21.9 & -0.69 & 25.5 & -0.53 & 27.0 & 0.55 \\
\hline 4 & 15.5 & 3.33 & 19.2 & -1.95 & 20.8 & 1.65 & 22.7 & -4.37 & 24.7 & 2.63 & 26.7 & 1.66 \\
\hline 5 & 15.8 & 1.46 & 18.7 & 0.71 & 20.8 & 1.65 & 21.0 & 3.45 & 25.5 & $-0 ., 53$ & 27,5 & -1.29 \\
\hline 6 & 16.6 & -3.53 & 18.9 & -0.35 & 21.4 & -1.18 & 20.8 & 4.37 & 25.2 & 0.66 & 26.9 & 0.92 \\
\hline $\begin{array}{c}\text { Average. } \\
\text { the arithmetic. }\end{array}$ & 16.03 & 0.00 & 18.83 & 0.00 & 21.15 & 0.47 & 21.75 & 0.00 & 25.37 & 0.00 & 27.15 & 0.00 \\
\hline $\min . \%$ & & -0.42 & & 0.71 & & -0.24 & & -0.69 & & -0.13 & & -0.18 \\
\hline $\max . \%$ & & -3.53 & & -1.95 & & -1.65 & & -4.37 & & 2.63 & & -1.66 \\
\hline
\end{tabular}

During cone introduction in samples with a cross-section arrangement of muscles it is possible to note a similar tendency: - at the reduction of an angle of cone the increase in an average value of depth of introduction from $27.3 \mathrm{~mm}$ is observed at $30^{\circ}$ до $34.87 \mathrm{~mm}$ for $10^{\circ}$.

It is necessary to notice that the difference between the analyzing sizes measured at a longitudinal and cross-section arrangement of muscles is considerable - from $49.1 \%$ to $38.5 \%$, accordingly strengthproperties of meat with cross-section mus- cles almost in one and a half time higher, than at is longitudinal muscles located, even for a vapour condition of meat. The given conclusion can be used by the manufacture of integral piece meat products.

In consiquence of biochemical processes, the formation of actomyosinal complex the muscular fabric in a condition postdeath stiffeness is condensed, firm properties are increasing, and consequently, the depth of penetration of identoris decreasing. On the basis of preliminary researches 
spent by us [6. 7] has been established that postdeath stiffeness comes in 40-44 hours from the moment of slaughter, therefore the further re- searches were spent at that period, the data of measurements is shown in Table 2.

Table 2

Change of depth of introduction of a cone in meat with is longitudinal and cross-section located muscles in 44 hours after slaughter.

\begin{tabular}{|c|c|c|c|c|c|c|c|c|c|c|c|c|}
\hline \multirow{3}{*}{$\begin{array}{c}\text { Number } \\
\text { of } \\
\text { measurements }\end{array}$} & \multicolumn{6}{|c|}{$\begin{array}{l}\text { Longitudinal muscle } \\
\text { Angle of a cone }\end{array}$} & \multicolumn{6}{|c|}{$\begin{array}{c}\text { Transverse muscle } \\
\text { Angle of a cone }\end{array}$} \\
\hline & \multicolumn{2}{|r|}{$30 \mathrm{P}$} & \multicolumn{2}{|r|}{$20 \mathrm{P}$} & \multicolumn{2}{|r|}{$10 \mathrm{P}$} & \multicolumn{2}{|r|}{$30 \mathrm{P}$} & \multicolumn{2}{|r|}{$20 \mathrm{P}$} & \multicolumn{2}{|r|}{$10 \mathrm{P}$} \\
\hline & $\mathrm{h}$ & $\begin{array}{c}\text { Meas. error } \\
\%\end{array}$ & $\mathrm{~h}$ & $\begin{array}{c}\text { Meas/ error } \\
\%\end{array}$ & $\mathrm{~h}$ & $\begin{array}{c}\text { Meas. error } \\
\%\end{array}$ & $\mathrm{~h}$ & $\begin{array}{l}\text { Meas. error } \\
\%\end{array}$ & $\mathrm{~h}$ & $\begin{array}{l}\text { Meas. error } \\
\%\end{array}$ & $\mathrm{~h}$ & $\begin{array}{c}\text { Meas. error } \\
\%\end{array}$ \\
\hline 1 & 19.2 & 1.03 & 21.7 & 2.18 & 25.6 & -1.65 & 26.4 & 3.30 & 33.4 & -1.01 & 35.1 & -0.67 \\
\hline 2 & 19.7 & -1.55 & 22.4 & -0.98 & 24.7 & 2.32 & 27.5 & -0.73 & 32.6 & 1.41 & 34.4 & 1.34 \\
\hline 3 & 18.9 & 2.58 & 21.9 & 1.28 & 24.8 & 1.52 & 27.1 & 0.73 & 32.4 & 2.02 & 35.4 & -1.53 \\
\hline 4 & 20.2 & -4.12 & 22.7 & -2.33 & 25.4 & -0.86 & 26.6 & 2.56 & 32.8 & 0.81 & 34.8 & 0.19 \\
\hline 5 & 18.7 & 3.61 & 22.3 & -0.53 & 25.5 & -1.26 & 28.5 & -4.40 & 33.3 & -0.71 & 35.3 & -1.24 \\
\hline 6 & 19.7 & -1.55 & 22.1 & 0.38 & 25.2 & -0.07 & 27.7 & -1.47 & 33.9 & $-2,52$ & 34.2 & 1.91 \\
\hline $\begin{array}{l}\text { Average. the } \\
\text { arithmetic. }\end{array}$ & 19.4 & 0.00 & 22.18 & 0.00 & 25.18 & 0.00 & 27.3 & 0.00 & 33.07 & 0.00 & 34.87 & 0.00 \\
\hline $\min , \%$ & & 1.03 & & 0.38 & & -0.07 & & 0.73 & & -0.71 & & 0.19 \\
\hline $\max , \%$ & & -4.12 & & -2.33 & & 2.32 & & -4.40 & & -2.52 & & -1.91 \\
\hline
\end{tabular}

For longitudinal located muscles, the depth of introduction of the cone, measured in 44 hours after slaughter, depending on an angle of indentor is in limits from 15.5 to $16.6 \mathrm{~mm}$ (angle $30^{\circ}$ ), from 18.5 to $19.2 \mathrm{~mm}$ (angle $20^{\circ}$ ), from 20.8 to $21.4 \mathrm{~mm}$ (angle $10^{\circ}$ ). In process of reduction of an angle of a cone the percent of an error of measured sizes decreases: from $3.53 \%$ to $1.65 \%$ for longitudinal the located muscles and from $4.37 \%$ to $1.66 \%$ for the cross-section ones.

The given fact allows to assume propose that the power of consumption increase with grinding equipment will increase that as a whole economic expenses of the enterprise for processing of a ton of meat raw materials in a condition of autolysis will increase approximately for $20 \%$.

Chosen, in the presented researches, the given effort of resistance of the product, equal $0.5 \mathrm{~kg}$ can correspond to its rational value. The size of effort of product resistance is considered to be rational if it provides the measurement of the depth of indentor's introduction no more than 0.9 from its maximum value and a possible thickness of investigated systems. In used dynamic penetrometer PPM-4 the conic indentors have height which is equal $40 \mathrm{~mm}$, and studing samples L.dorsi have a thickness from 50 to $80 \mathrm{~mm}$. Then rational depth of introduction should be equal $40 \times 0.9=36 \mathrm{~mm}$. In our case, at use rational conic indentors with an angle at top $10^{\circ}$, according to Tables 1.2 , the maximum depth makes $35.4 \mathrm{~mm}$, and minimum is $21.2 \mathrm{~mm}$ that can be put in a rational limit of measurement.

\section{CONCLUSION}

Analyzing the received experimental data, we see that at using conic indentors in the given range of corners at top from $10^{\circ}$ to $30^{\circ}$, the greatest value of depth of immersing we receive at a cone $10^{\circ}$.

The chosen cone provides the minimum disorder of experimental data that allows to consider it rational and to use it for studying of rheological characteristics of whole muscle meat raw materials. For carrying out of measurements of whole muscle raw materials, rational effort of resistance is equal $0.5 \mathrm{~kg}$. The process of penetration should be implemented in a longitudinal arranged muscle to provide a minimum measurement error. 
Therefore, to assess the rheological properties of meat by penetration of efficient use of dynamic penetrometers with conic indentors. The measurements should be carried out at selected conditions.

\section{REFERENCES}

[1] Aitbek Kakimov, Zhanibek Yessimbekov, Aigerim Bepeyeva, Bolat Kabulov and Zhainagul Kakimova: Consistency Cone Penetrometry for Food Products. Pakistan Journal of Nutrition, 14 (11), 837-840 (2015).

[2] Kosoy V. D., Malyshev A. D., Yudina S. B.: Engineering rheology in the production of sausages, M., KolosS, 2005, p. 262

[3] Kosoy V. D., Dorohov V. P.: Improving the production of sausages (theoretical foundations, processes, equipment, technology, formulations and quality control), M., DeLi print, 2006, p-p 72-99.

[4] Migdał W., Živković B., Nowocień A., Przeor I., Palka K., Natonek-Wiśniewska M., Wojtysiak D., Walczycka M., Duda I.: Chemical composition and texture parameters of loin from polish landrace fatteners slaughtered in different age. J. Biotechnology in Animal Husbandry, 23 (5-6), 277-282 (2007).

[5] Poldvere A., Lepasalu L., Tanavots A., Olt J., Sannik U., Sats A., Saar R., Martinson R. and Poikalainen V.: An alternative method for meat shear energy estimation during ageing. J. Agronomy Research, 12 (3), 793-800 (2014).

[6] Savinok O. N., Azarova N. G., Kosoy V. D., Rizhov S. A.: Kinetics of beef maturation in one-step cooling $J$. Meat. Industry, 5, 58-62 (2011).

[7] Savinok O. N.: The kinetics of the functional meat parameters depending on the duration of its exposure after slaughter. J. Storage and processing of agricultural. № 4. pp. 35-41 (2014). 